JKM (Jurnal Kebidanan Malahayati),Vol 7,No.2.April 2021,

ISSN (Print) 2476-8944 ISSN (Online) 2579-762X, Hal 287-294

\title{
PEMBERIAN TERAPI MURATTAL AL-QURAN TERHADAP KUALITAS TIDUR IBU HAMIL PRIMIGRAVIDA TRIMESTER III
}

\author{
Noviyanti ${ }^{1 *}$, Rahmi $^{2}$, Ratna Dewi ${ }^{3}$, Nurdahliana ${ }^{4}$ \\ 1,3Program Studi D-IV Kebidanan Poltekkes Kemenkes Aceh \\ 2,4Dosen Jurusan Kebidanan Poltekkes Kemenkes Aceh \\ *Korespondensi Email : noviyanti@poltekkesaceh.ac.id
}

\section{ABSTRACT GIVING MURATTAL AL-QURAN THERAPY ON QUALITY TRIMESTER PRIMARY PREGNANT MOTHER'S SLEEP III}

Background : Expecting mothers experienced different discomforts which were frequently felt in the third trimester, a waiting period in which the pregnant mothers started to be alert of delivering a baby. These discomforts resulted in disturbance of activities of the expectants. Sleep problem was mostly occured during this trimester which might decrease sleep quality. To overcome the complaint, there should be a way to increase sleep quality of the pregnant women. One of them is Murattal Qur'an.

Purpose : This study was aimed at finding out the effect of Murattal Qur'an on third semester toward sleep quality of the pregnants.

Methods : This research belonged to a quasi-experimental with a pretest-posttest control group design. The population in this study were all pregnant women in the third trimester primigravida in the working area of the Kuta Baro Health Center, Aceh Besar. The sample was 40 pregnant women who were divided into the control group and the treatment group. The treatment group listened to the Murattal Quran chapter Ar-Rahman on Android for 7 nights before going to bed. Data was analysed by using the Wilcoxon test because the data were not normally distributed.

Results: The obtained significant value $(p)$ of the treatment group of before and after therapy was 0.000 lower than $0.05(p=0.000<0.05)$

Conclusion: There is an effect of giving Murattal Al-Quran therapy in the third trimester primigravida on the quality of mother's sleep.

Suggestion: It hoped that it increased the active role of Midwives to provide information to pregnant women about the way to overcome the sleep disorders of the third trimester pregnant women was by by listening to the murattal Quran.

Keywords: Murattal Al-Quran, Sleep Quality, Primigravida, Third Trimester.

\section{ABSTRAK}

Latar Belakang : Ketidaknyamanan yang dirasakan oleh ibu hamil paling sering dirasakan saat trimester III. Trimester III merupakan masa menunggu kelahiran bayinya. Ketidaknyamanan yang dirasakan ibu mengakibatkan aktivitas sehari-hari ibu hamil menjadi terganggu. Gangguan tidur merupakan Keluhan yang paling sering terjadi pada ibu hamil trimester III. Gangguan ini menyebabkan kualitas tidur ibu menurun. Salah satu cara pendekatan untuk meningkatkan kualitas tidur ibu hamil adalah mendengarkan lantunan ayat Al-Quran.

Tujuan : Mengetahui pengaruh pemberian terapi murattal Al-Quran pada primigravida trimester III terhadap kualitas tidur ibu.

Metode : Jenis penelitian adalah quasi-eksperimen dengan pendekatan pretest-posttest control group design. Populasi adalah primigravida trimester III di wilayah kerja Puskesmas Kuta Baro Kabupaten Aceh Besar. Jumlah sampel 40 ibu hamil yang dibagi menjadi kelompok kontrol dan kelompok perlakuan. Kelompok perlakuan mendengarkan murattal Al-Quran surah Ar-Rahman dengan menggunakan HP Android selama 7 malam sebelum tidur. Analisa data menggunakan Uji Wilcoxon karena data berdistribusi tidak normal. 
Hasil : Nilai signifikan pada kelompok perlakuan terhadap kualitas tidur ibu sebelum dan sesudah diberikan terapi adalah $p=0,000$ lebih kecil dari nilai 0,05.

Kesimpulan : Terdapat pengaruh pemberian terapi murattal Al-Quran pada primigravida trimester III terhadap kualitas tidur ibu.

Saran : Meningkatkan peran aktif bidan dalam memberikan informasi kepada ibu hamil tentang asuhan ketidaknyaman ibu hamil trimester III yaitu masalah gangguan tidur dengan mendengarkan murattal Al-Quran.

Kata Kunci: Murattal Al-Quran, Kualitas tidur, Primigravida, Trimester III.

\section{PENDAHULUAN}

Kehamilan adalah masa yang dimulai dari konsepsi sampai lahirnya janin yang lamanya 40 minggu atau 280 hari terhitung mulai hari pertama haid terakhir. Kehamilan terbagi atas 3 trimester. Trimester I usia kandungan 1-14 minggu, trimester II usia kandungan 14-25 minggu dan trimester III usia kandungan 27-40 minggu. Selama kehamilan ibu mengalami banyak perubahan baik perubahan anatomi maupun perubahan fisiologis (Soma-Pillay, 2016) dan (Margareth, 2019).

Keluhan setiap Ibu hamil berbeda-beda pada setiap trimester kehamilannya. Pada timester pertama, ibu hamil sering mengeluh mual dan muntah saat pagi hari. Pada trimester kedua, umumnya kondisi ibu lebih stabil karena sudah melewati masa kritis. Ketidaknyamanan lebih sering terjadi pada trimester ketiga. Trimester III merupakan masa menunggu dan waspada karena akan menunggu kelahiran bayinya. Ketidaknyamanan ini mengakibatkan aktivitas sehari-hari ibu hamil menjadi terganggu (Enny, 2017) (Indrianingrum, 2020) dan (Panuntun, 2016).

Beberapa faktor dominan yang menstimulasi terjadinya gangguan kualitas tidur ibu hamil pada trimester III antara lain kecemasan menghadapi kehamilan, ketidaknyamanan selama kehamilan akibat seringnya buang air kecil, hipersaliva dan mendengkur serta kram terutama pada ibu primigravida trimester III (Palifiana, 2018) (Wardani, 2018). Gangguan kualitas tidur adalah ketidaknyamanan yang sering terjadi pada kehamilan trimester III. Ketidaknyamanan ini disebabkan sakit punggung, frekuensi kencing, gerakan janin, GERD dan ketidaknyamanan kaki. Durasi dan kualitas tidur kemungkinan disebabkan faktor hormonal, fisiologis, metabolik, psikologik dan postur tubuh.Kondisi ini dapat mempengaruhi kesehatan dan kualitas hidup ibu serta dapat mempengaruhi kehamilannya. Hasil penelitian di San Fracisco, ibu hamil yang tidur malam kurang 6 jam kemungkinan akan mengalami persalinan lama dan 4,5 kali kemungkinan mengalami operasi caesar (Hashmi, 2016) dan (Sukorini, 2017).

Kualitas tidur ibu hamil trimester III secara signifikan lebih rendah dibanding kualitas tidur ibu hamil pada trimester satu dan dua. Hal Ini ditunjukkan dengan meningkatnya frekuensi bangun saat malam hari, durasi tidur menjadi lebih pendek, merasa lelah saat bangun tidur pagi, dan mengantuk pada saat siang hari. Ibu hamil trimester III juga mengalami resiko kecemasan menjelang persalinan, dampak dari kecemasan ini juga akan menurunkan kualitas tidur ibu hamil. Semakin tinggi kecemasan yang dialami ibu hamil trimester III, maka kualitas tidur yang dimiliki juga semakin rendah (Hutchison, 2012) dan (Fitriana, 2021).

Ibu hamil yang mengalami emotional distress pada usia kehamilan 30 minggu mengakibatkan ibu berisiko mengalami persalinan preterm. Kondisi ini menyebabkan usia kehamilan menjadi lebih pendek dan meningkatkan resiko komplikasi kehamilan dan membutuhkan tindakan sectio caesaria atau induksi untuk membantu proses persalinan (Lukasse, 2014) dan (Sukorini, 2017).

Salah satu cara pendekatan spiritual yang efektif untuk membuat pasien menjadi tenang yaitu mendengarkan lantunan ayat suci Al-Qur'an (terapi murattal Al-Qur'an). Bacaan 
Al-Quran secara umum memiliki efek fisiologis dan psikologis yang sangat baik seperti menenangkan, meningkatkan kreatifitas, meningkatkan kekebalan tubuh, meningkatkan kemampuan konsentrasi, menyembuhkan berbagai penyakit, menciptakan suasana damai, meredakan ketegangan saraf otak, meredakan kegelisahan, mengatasi rasa takut, memperkuat kepribadian, meningkatkan kemampuan berbahasa, dan meningkatkan intelegensi. Murattal merupakan bacaan AlQur'an yang dibacakan oleh Qori' atau Qori'ah sesuai dengan tartil dan tajwid yang mengalun indah yang dikemas dalam media audio seperti kaset, CD atau data digital. Lantunan ayat suci Al-Qur'an secara fisik mengandung unsur suara manusia, suara manusia merupakan alat penyembuh yang menakjubkan dan alat yang paling mudah dijangkau (Azis, 2015) (Syafei, 2018)

Mendengarkan Al-Qur'an memiliki dampak yang luar biasa, karena dampak dari keselarasan yang sempurna dalam pengulangan kata dan huruf, dampak irama yang seimbang terhadap ayat-ayat Al-Quran, dampak dari informasi pada masing-masing ayat, dan harmonisasi yang indah. Terapi suara mendengarkan bacaan Al-Quran mempunyai pengaruh yaitu berupa perubahan-perubahan arus listrik di otot, perubahan sirkulasi darah, perubahan detak jantung, dan kadar darah pada kulit. Perubahan tersebut menunjukkan adanya relaksasi atau penurunan ketegangan otot syaraf (Hakim, 2012). Penelitian (Wulandari, 2015) menunjukkan bahwa ada pengaruh mendengarkan murattal Al-Quran terhadap penurunan tingkat kesulitan tidur dan kondisi ini juga memberikan efek yang menetap.

\section{HASIL DAN PEMBAHASAN}

Puskesmas Kuta Baro adalah puskesmas yang berada didesa Lambro Bileu di kecamatan Kuta Baro yang berada dalam wilayah kabupaten Aceh Besar di Provinsi Nanggroe Aceh Darussalam dengan jarak 10,5 $\mathrm{km}$ dari Kota Banda Aceh, dengan luas wilayah 140,33 km2. Adapun batas wilayah Kecamatan Kuta Baro adalah sebagai berikut :

1. Sebelah Barat berbatasan dengan Kecamatan Krueng Barona Jaya

2. Sebelah Utara berbatasan dengan Kecamatan Darussalam

3. Sebelah Timur berbatasan dengan Kecamatan Ingin Jaya

4. Sebelah Selatan berbatasan dengan Kecamatan Montasik

\section{Analisa Univariat}

Berdasarkan tabel 1 terlihat bahwa kelompok kontrol dan kelompok perlakuan mayoritas berumur < 30 tahun yaitu $90 \%$. Kelompok kontrol mayoritas pendidikan tingkat SMP dan SMA yaitu masing-masing 45\% dan kelompok perlakuan, mayoritas pendidikan SMA yaitu $65 \%$. Usia kehamilan pada kelompok kontrol mayoritas adalah 7 bulan sebesar $60 \%$ sedangkan kelompok perlakuan mayoritas adalah usia kehamilan 8 bulan yaitu $70 \%$.

Tabel 1.

Karakteristik Responden

\begin{tabular}{lcccc}
\hline \multirow{2}{*}{ Karakteristik Responden } & \multicolumn{2}{c}{ Kelompok Kontrol } & \multicolumn{2}{c}{ Kelompok Perlakuan } \\
\cline { 2 - 5 } & $\mathbf{N}$ & $\%$ & $\mathbf{N}$ & $\%$ \\
\hline Umur & 18 & 90 & 18 & 90 \\
$<30$ tahun & 2 & 10 & 2 & 10 \\
$\geq 30$ tahun & & & & \\
Pendidikan & 9 & 45 & 5 & 25 \\
SD/ SMP & 9 & 45 & 13 & 65 \\
SMA & 2 & 10 & 2 & 10 \\
Diploma/ S1 & & & & \\
Usia Kehamilan & 12 & 60 & 6 & 30 \\
7 Bulan & & &
\end{tabular}




\begin{tabular}{ccccc}
8 Bulan & 8 & 40 & 14 & 70 \\
\hline Jumlah & 20 & 100 & 20 & 100 \\
\hline
\end{tabular}

Tabel 2.

Distribusi Frekuensi Responden berdasarkan Kualitas Tidur Primigravida Trimester III pada Kelompok Kontrol Uji Pre-Test Dan Post-Test Di Wilayah Kerja Puskesmas Kuta Baro Kabupaten Aceh Besar

\begin{tabular}{lcccc}
\hline \multirow{2}{*}{ Kualitas Tidur } & \multicolumn{2}{c}{ Pre-Test } & \multicolumn{2}{c}{ Post-Test } \\
\cline { 2 - 5 } & $\mathbf{f}$ & $\mathbf{( \% )}$ & $\mathbf{f}$ & $(\%)$ \\
\hline Baik & 2 & 10 & 2 & 10 \\
Buruk & 18 & 90 & 18 & 90 \\
\hline \multicolumn{1}{c}{ Jumlah } & 20 & 100 & 20 & 100 \\
\hline
\end{tabular}

Tabel 3.

Distribusi Frekuensi Responden berdasarkan Kualitas Tidur Primigravida Trimester III pada Kelompok Perlakuan Uji Pre-Test Dan Post-Test Di Wilayah Kerja Puskesmas Kuta Baro Kabupaten Aceh Besar

\begin{tabular}{lcccc}
\hline \multirow{2}{*}{ Kualitas Tidur } & \multicolumn{2}{c}{ Pre-Test } & \multicolumn{2}{c}{ Post-Test } \\
\cline { 2 - 5 } & $\mathbf{f}$ & $\mathbf{( \% )}$ & $\mathbf{f}$ & $\mathbf{( \% )}$ \\
\hline Baik & 2 & 10 & 8 & 40 \\
Buruk & 18 & 90 & 12 & 60 \\
\hline \multicolumn{1}{c}{ Jumlah } & 20 & 100 & 20 & 100 \\
\hline
\end{tabular}

Berdasarkan tabel 2 di atas menunjukkan bahwa dari 20 responden, 90\% responden mengalami kualitas tidur buruk saat Pre-Test dan Post-Test.

Berdasarkan tabel 3 di atas menunjukkan bahwa dari 20 responden, $90 \%$ responden mengalami kualitas tidur buruk pada saat Pre-Test, namun setelah diberikan perlakuan kualitas tidur buruk responden menurun menjadi $60 \%$.

Analisa Bivariat

Tabel 4.

Hasil Uji Normalitas Data

\begin{tabular}{lccc}
\hline \multicolumn{1}{c}{ Kelompok } & Mean & SD & Sig \\
\hline Kontrol & 9.82 & 3.096 & 0.226 \\
Perlakuan & 9.80 & 3.674 & 0.015 \\
\hline
\end{tabular}

Berdasarkan Tabel 4 didapatkan hasil uji normalitas bahwa data Kelompok Kontrol lebih besar dari 0.05 , yang berarti bahwa data tersebut berdistribusi normal. Sedangkan data Kelompok Perlakuan nilainya lebih kecil dari 0.05 yang berarti bahwa data berdistribusi tidak normal. Uji beda yang digunakan untuk melihat perbedaan kualitas tidur ibu sebelum dan sesudah diberikan terapi murattal AlQuran adalah uji Wilcoxon.

Berdasarkan Tabel 5 dibawah menunjukkan bahwa nilai signifikan lebih kecil dari nilai 0,05 yang berarti bahwa terdapat perbedaan kualitas tidur sebelum dan sesudah diberikan terapi murattal Al-Quran pada ibu primigravida trimester III di wilayah kerja puskesmas Kuta Baro kabupaten Aceh Besar. 
JKM (Jurnal Kebidanan Malahayati),Vol 7,No.2.April 2021,

ISSN (Print) 2476-8944 ISSN (Online) 2579-762X, Hal 143-

Tabel 5.

\section{Hasil Uji Beda Kualitas Tidur Ibu Primigravida Trimester III pada Kelompok Perlakuan Sebelum dan Sesudah diberikan Terapi Murattal Al-Quran Di Wilayah Kerja Puskesmas Kuta Baro Kabupaten Aceh Besar}

\begin{tabular}{lccc}
\hline \multicolumn{1}{c}{$\begin{array}{l}\text { Kelompok } \\
\text { Perlakuan }\end{array}$} & \multicolumn{2}{c}{ Mean Rank } & \multirow{2}{*}{ Sig } \\
\cline { 2 - 3 } & Positif & Negatif & \\
\hline $\begin{array}{l}\text { Pretest } \\
\text { Posttest }\end{array}$ & 2.00 & 9.44 & 0.000 \\
\hline
\end{tabular}

\section{PEMBAHASAN}

Hasil penelitian menunjukkan bahwa dari 20 responden, yang memiliki kualitas tidur buruk yaitu 18 responden (90\%) dan responden yang memiliki kualitas tidur baik yaitu 2 responden $(10 \%)$ (tabel 2). Hal ini sesuai dengan hasil penelitian Panuntun (2016), bahwa bentuk ketidaknyamanan fisik yang paling banyak dialami ibu hamil trimester III adalah kualitas tidur buruk (96,7\%). Kondisi ini harus di atasi, karena dapat berdampak negatif bagi ibu dan janin.

Hasil analisis dengan menggunakan uji Wilcoxon menunjukkan bahwa terdapat perbedaan yang signifikan kualitas tidur ibu primigravida trimester III sebelum dan sesudah pemberian terapi murattal Al-Quran di wilayah kerja puskesmas Kuta Baro Kabupaten Aceh Besar dengan nilai p $0.000(<0.05)$. Tidur merupakan salah satu kebutuhan fisiologis manusia yang berfungsi untuk mengembalikan tenaga agar dapat beraktifitas kembali dan juga untuk menghilangkan kelelahan jasmani dan kelelahan mental (Sinaga, 2013). Tidur merupakan salah satu cara agar tubuh dapat beristirahat, dengan istirahat sistem kekebalan tubuh akan menjadi lebih kuat (Wulandari, 2015) dan (Dewiani, 2017).

Ibu hamil sering mengalami insomnia, terbangun saat malam hari, dan gelisah di akhir kehamilan yang dapat mempengaruhi kualitas hidup ibu hamil. Kekurangan tidur memiliki dampak yang tidak baik bagi kesehatan. Aktifitas fisik dan psikis juga dapat terganggu bila tubuh kekurangan istirahat (Hollenbach, 2013). Gangguan tidur pada ibu hamil seperti insomnia, gelisah dapat mengakibatkan komplikasi pada kehamilan, diabetes gestasional, hipertensi kehamilan serta depresi post partum. Upaya mengatasi gangguan tidur yang umumnya terjadi pada ibu hamil terutama ibu primigravida dapat secara farmakologi dan non-farmakologi. Pendekatan secara farmakologi pada ibu hamil memiliki efek yang lebih berbahaya dibanding non farmakologi. Tindakan yang dapat dilakukan untuk mengatasi gangguan tidur atau diantaranya terapi musik (terapi suara), relaksasi otot, pijat, hipnotis, yoga dan teknik pernafasan(Rashed, 2016) dan (Maryani, 2020).

Terapi suara dengan mendengarkan bacaan Al-Quran memiliki pengaruh pada penurunan ketegangan otot saraf (rileks). Yaitu dengan merangsang otak memproduksi zat kimia (neuropeptide) yang memberikan umpan balik berupa kenyamanan. Pada beberapa penelitian telah menunjukkan bahwa terdapat pengaruh yang signifikan terapi murattal AlQuran terhadap kualitas tidur pada lansia (Oktora, 2018) dan (Rizki Yuniarti, 2020). Terapi murattal Al-Quran juga dapat meningkatkan kualitas tidur pada remaja (Kurniyawan, 2018) dan (Yuliani, 2018).

Hasil penelitian menunjukkan bahwa dari 20 responden yang sudah diberikan terapi murattal Al-Quran yang memiliki kualitas tidur buruk mengalami penurunan dari 18 responden (90\%) menjadi 12 responden $(60 \%)$ dan responden memiliki kualitas tidur baik yaitu 8 responden (40\%) (tabel 4.4). Berdasarkan hasil penelusuran belum ditemukan penelitian secara langsung tentang murattal Al-Quran dengan kualitas tidur pada ibu hamil.

Ibu hamil yang mengalami kecemasan biasanya ditandai dengan rasa gelisah, takut dan tidak dapat istirahat (gangguan tidur). Pendekatan dengan Al-Quran akan memberikan rasa tenang dan nyaman. Terapi murattal mempengaruhi hormon endhorfin yang membuat perasaan rileks sehingga efektif mengurangi kecemasan pada ibu hamil. Pembacaan Al-Qur'an dengan irama tempo 
yang lambat dan stabil dapat menurunkan ketegangan syaraf dan memberikan efek relaksasi (Nugraheni, 2018) dan (Rinata, 2018).

Salah satu faktor yang mempengaruhi kualitas maupun kuantitas tidur ibu hamil pada trimester III adalah kecemasan. Kecemasan menyebabkan perasaan sulit untuk rileks saat akan memulai tidur. Kecemasan meningkatkan kadar norepinefrin dalam darah melalui stimulasi sistem saraf simpatis. Perubahan kimia ini menyebabkan kurangnya waktu tidur tahap IV NREM dan tidur REM serta lebih banyak perubahan dalam tahap tidur dan lebih sering terbangun. Kecemasan ibu hamil trimester III semakin tinggi terutama saat mendekati proses melahirkan dan hal ini yang menyebabkan ibu untuk sulit tidur dan sering terbangun dimalam hari (Komalasari, 2012) dan (Utami, 2021).

Suara lantunan murattal Al-Quran akan menstimulasi gelombang delta pada otak manusia, ini akan menyebabkan seseorang menjadi tenang, tentram dan nyaman bahkan untuk non muslim. Gelombang ini diperlukan tubuh untuk kondisi tenang, atau keadaan tidur yang pulas. Terapi suara dengan mendengarkan bacaan Al-Quran mempunyai pengaruh yaitu berupa perubahan-perubahan arus listrik di otot, perubahan sirkulasi darah, perubahan detak jantung, dan kadar darah pada kulit. Perubahan tersebut menunjukkan adanya relaksasi atau penurunan ketegangan otot syaraf. yang memberikan umpan balik berupa kenikmatan atau kenyamanan (Wulandari, 2015) dan (Aprilini, 2019).

Peneliti berasumsi bahwa terapi murattal Al-Quran sangat efektif dianjurkan kepada ibu hamil terutama pada trimester III karena dapat memberikan ketenangan dan rileks. Ketidaknyamanan ibu hamil pada trimester III antara lain gangguan tidur, salah satu penyebabnya adalah kecemasan. Terapi murattal Al-Quran tidak memiliki efek samping, murah dan mudah.

\section{SIMPULAN}

Terdapat pengaruh pemberian terapi murattal Al-Quran pada primigravida trimester III terhadap kualitas tidur ibu hamil.

\section{SARAN}

Meningkatkan peran aktif bidan dalam memberikan informasi kepada ibu hamil tentang asuhan ketidaknyaman ibu hamil trimester III yaitu masalah gangguan tidur dengan mendengarkan murattal Al-Quran.

\section{DAFTAR PUSTAKA}

Aprilini, M., Mansyur, A. Y., \& Ridfah, A. (2019). Efektivitas Mendengarkan Murottal Al-Quran Dalam Menurunkan Tingkat Insomnia Pada Mahasiswa. Psikis: Jurnal Psikologi Islami, 5(2), 146-154.

Azis, W., Nooryanto, M., \& Andarini, S. (2015). Terapi Murotal Al-Qur'an Surat Arrahman Meningkatkan Kadar $\beta$ Endorphin dan Menurunkan Intensitas Nyeri pada Ibu Bersalin Kala I Fase Aktif. Jurnal Kedokteran Brawijaya, 28(3), 213-216.

Dewiani, C., \& Sulastri, S. K. (2017). Upaya Pemenuhan Istirahat Dan Tidur Pada Ibu Hamil Trimester III. Doctoral dissertation, Universitas Muhammadiyah Surakarta.

Enny, F. (2017). Buku ajar Asuhan kehamilan disertai daftar tilik. Universitas 'Aisyiyah Yogyakarta.

Fitriana, N. (2021). Perubahan Kualitas Tidur Ibu Hamil Trimester III Melalui Pregnancy Massage. Jurnal Keperawatan Silampari, 4(2), 359-367.

Hakim, H. L. (2012). Terapi Qurani: untuk Kesembuhan dan Rizki Tak Terduga anda akan memperoleh segalanya (Ketentraman, Keberkahan, Keselamatan).

Hashmi, A. M., Bhatia, Bhatia, S.K., Bhatia, S.K., \& Khawaja, I.S. (2016). Insomnia during pregnancy : Diagnosis and Rational Interventions. Pakistan Journal of Medical Sciences, 32 (4), 1030.

Hollenbach, D., Broker, R., Herlehy, S., \& Stuber, K. (2013). Nonpharmacological interventions for sleep quality and insomnia during pregnancy: a systematic review. The 


\section{JKM (Jurnal Kebidanan Malahayati),Vol 7,No.2.April 2021, ISSN (Print) 2476-8944 ISSN (Online) 2579-762X, Hal 143-}

Journal of the Canadian Chiropractic Association, 57(3), 260.

Hutchison, B. L., Stone, P.R, McCowan, L.M, Stewart, A.W, Thompson, J.M, \& Mitchell, E.A. (2012). A Postal survey of maternal sleep in late pregnancy. BMC Pregnancy \& Childbirth, 12 (1), 17.

Indrianingrum, I. (2020). KETIDAKNYAMANAN KELUHAN PUSING PADA IBU HAMIL DI WILAYAH KERJA PUSKESMAS GRIBIG KABUPATEN KUDUS. Jurnal IImu Keperawatan dan Kebidanan, 11(2), 265-271.

Komalasari, D. (2012). Hubungan antara tingkat kecemasan dengan kualitas tidur pada ibu hamil trimester III Students e-Journal, 1(1), 31.

Kurniyawan, E. H. (2018). Murottal Al-Quran Therapy to Increase Sleep Quality in Nursing Students. UNEJ e-Proceeding, 7-14.

Lukasse, M., Helbig, A., Benth, J. Š., \& Eberhard-Gran, M. (2014). . , . (2014). Antenatal maternal emotional distress and duration of pregnancy. PloS one, 9(7), e101682.

Margareth, Z. H. (2019). Kehamilan, Persalinan, dan Nifas dilengkapi dengan patologi.

Maryani, S., Amalia, R., \& Sari, M. H. N. (2020). PIJAT HAMIL SEBAGAI TERAPI NON FARMAKOLOGIS

DALAM PENANGANAN KETIDAKNYAMANAN KEHAMILAN TRIMESTER III. Jurnal Sains Kebidanan, 2(2), 15-20.

Nugraheni, N., \& Romdiyah, R. (2018). Perbedaan Perlakuan Senam Hamil Dan Terapi Murotal Terhadap Tingkat Kecemasan Ibu Hamil Trimester III. Jurnal Penelitian dan Pengabdian kepada Masyarakat UNSIQ, 5(2), 226236.

Oktora, S. P. D., \& Purnawan, I. (2018). Pengaruh Terapi Murottal Al Qur'an terhadap Kualitas Tidur Lansia di Unit Rehabilitasi Sosial Dewanata Cilacap. Jurnal Keperawatan Soedirman, 11(3), 168-173.

Palifiana, D. A. W., S. (2018). Hubungan ketidaknyamanan dalam kehamilan dengan kualitas tidur ibu hamil trimester III di klinik pratama asih waluyo jati. Prosiding Seminar Nasional, Seri 8.

Panuntun, R. A. H., E.D (2016). . (2016). Gambaran Ketidaknyamanan Fisik dan Psikologis pada Ibu Hamil Trimester III di Puskesmas Kabupaten Bantul Daerah Istimewa Yogyakarta (Doctoral dissertation, Universitas Gadjah Mada).

Rashed, A. B. A. A., Khalil, A. K., \& Shereda, H. M. A. (2016). Effect of nonpharmacological interventions on sleep quality during pregnancy among primigravida. IOSR Journal of Nursing and Health Science, 5(6), 7-15.

Rinata, E., \& Andayani, G. A. (2018). Karakteristik ibu (usia, paritas, pendidikan) dan dukungan keluarga dengan kecemasan ibu hamil trimester III. Medisains, 16(1), 14-20.

Rizki Yuniarti, R. Y. (2020). Pengaruh Terapi Dzikir terhadap Insomnia pada Lansia: Sebuah Tinjauan Sistematis. Doctoral dissertation, STIK Bina Husada Palembang.

Sinaga, T. (2013). Musik klasik sebagai alternatif mengatasi gangguan tidurpada penderita insomnia. Jurnal pengabdian kepada masyarakat, 19(72), 88-97.

Soma-Pillay, P., Catherine, N. P., Tolppanen, H., Mebazaa, A., Tolppanen, H., \& Mebazaa, A. (2016). Physiological changes in pregnancy. Cardiovascular journal of Africa, 27(2), 89.

Sukorini, M. U. (2017). Hubungan Gangguan Kenyamanan Fisik Dan Penyakit Dengan Kualitas Tidur Ibu Hamil Trimester III. The Indonesian Journal of Public Health, 12(1), 1-12.

Syafei, A., \& Suryadi, Y. (2018). Pengaruh pemberian terapi audio Murottal Qur'an surat Ar-Rahman terhadap tingkat kecemasan pada pasien preoperasi Katarak Senilis. Jurnal Kesehatan, 9(1), 126-130.

Utami, R. J., Indarwati, R., \& Pradanie, R. (2021). Analisa Faktor Yang Mempengaruhi Kualitas Tidur Lansia Di Panti. Jurnal Health Sains, 2(3), 362380. 
Wardani, H. W., Agustina, R., \& Damayanti, E. A. F. (2018). Tingkat Kecemasan dengan KualitasTidur Ibu Hamil Primigravida Trimester III. Dunia Keperawatan: Jurnal Keperawatan dan Kesehatan, 6(1), 1-10. .

Wulandari, E. D., \& Trimulyaningsih, N. (2015). Mendengarkan Murattal Al-Qur'an untuk Menurunkan Tingkat Insomnia. JIP Jurnal Intervensi Psikologi, 7(1), 4055.

Yuliani, D. R., Widyawati, M. N., Rahayu, D. L., Widiastuti, A., \& Rusmini, R. (2018). Terapi Murottal sebagai Upaya Menurunkan Kecemasan dan Tekanan Darah pada Ibu Hamil dengan Preeklampsia: Literature Review Dilengkapi Studi Kasus. Jurnal Kebidanan, 8(2), 79-98. 